\title{
Novos gêneros, novas espécies e redescrição em Hemilophini (Coleoptera, Cerambycidae, Lamiinae) das Américas
}

\author{
Maria Helena M. Galileo ${ }^{1,3}$ \& Ubirajara R. Martins 2,3 $^{2,3}$
}

\author{
${ }^{1}$ Museu de Ciências Naturais, Fundação Zoobotânica do Rio Grande do Sul, Rua Dr. Salvador França, 1427, 90690-000 Porto Alegre-RS, Brasil. \\ galileo@fzb.rs.gov.br \\ ${ }^{2}$ Museu de Zoologia, Universidade de São Paulo, Caixa Postal 42594, 04218-970 São Paulo-SP, Brasil. urmsouza@usp.br \\ ${ }^{3}$ Pesquisador do $\mathrm{CNPq}$
}

\begin{abstract}
New genera, new species and redescription in Hemilophini (Coleoptera, Cerambycidae, Lamiinae) from the Americas. New taxa described from El Salvador: Eranina sororcula sp. nov. (La Libertad). From Honduras: E. pallida sp. nov. (department not indicated). From Costa Rica: Mexicoscylus nigritarse sp. nov. (Guanacaste) and Cotyabanycha gen. nov., type species, $C$. ocularis sp. nov. (Limón). From Colombia and Ecuador: Sybaguasu mirim sp. nov. (Meta and Napo). From Ecuador: Piampatara antennata sp. nov. (Napo), Adesmus simile sp. nov. (Manabi), A. alboniger sp. nov. (Napo), A. swifti sp. nov. (Loja). From Bolivia: Potiapunga gen. nov., type species P. lata sp. nov. (Santa Cruz). Phoebe spegazzinii Bruch, 1908 is recorded for Ecuador (Manabi) and its chromatic variation is commented.
\end{abstract}

KEYWORDS. Central America; Insecta; new taxa; South America; taxonomy.

Recebemos para estudo vultoso material de Hemilophini (Lamiinae, Cerambycidae) de diversas procedências. Nesta contribuição, descrevemos dois gêneros novos e dez novas espécies nos gêneros: Eranina Monné, 2005, Mexicoscylus Galileo \& Martins, 2011, Cotyabanycha gen. nov., Sybaguasu Martins \& Galileo, 1991, Adesmus Lepeletier \& A.-Serville, 1825 e Potiapunga gen. nov.

O nome Eranina foi proposto por Monné (2005) para substituir Erana Bates, 1866, e o gênero foi revisto por Galileo \& Martins (2008) com apresentação de chave para identificação das 35 espécies que então o constituíam. Nesta contribuição descrevemos mais duas espécies em Eranina.

O gênero Mexicoscylus foi estabelecido por Martins \& Galileo (2011) para duas espécies mexicanas. Ora acrescentamos mais uma espécie da Costa Rica, o que amplia a sua distribuição para a América Central.

Uma chave para as sete espécies, então conhecidas, de Sybaguasu foi publicada por Martins \& Galileo (2004). É descrita mais uma espécie para o gênero, com dimensões muito reduzidas.

O gênero Adesmus é dos mais diversificados da tribo e envolve 61 espécies ocorrentes do México até a Argentina, mas não representadas na Patagônia e no Chile. Uma chave para as espécies do gênero foi publicada por Galileo \& Martins (1999) então com 42 espécies. Depois de 1999, foram descritas mais 19 espécies. Ora descrevemos mais três espécies, todas do Equador.

\section{MATERIAL}

O material citado no texto pertence às instituições: CASC, California Academy of Sciences, San Francisco, EUA; LGBC,
Coleção Larrry G. Bezark, Sacramento, Califórnia, EUA; MACN, Museo Argentino de Ciencias Naturales "Bernardino Rivadavia", Buenos Aires, Argentina; MNKM, Museo Noel Kempff Mercado, Santa Cruz de la Sierra, Bolívia; MZSP, Museu de Zoologia, Universidade de São Paulo, São Paulo, Brasil; USNM, National Museum of Natural History, Washington, DC, EUA.

\section{Sybaguasu mirim sp. nov.}

(Fig. 1)

Etimologia. Tupi, mirim = pequeno, diminuto; alusivo à dimensão reduzida.

Cabeça preta; fronte ou toda alaranjada ou quase toda preta. Genas e faixa longitudinal atrás dos olhos, alaranjadas. Antenas atingem os ápices dos élitros aproximadamente na extremidade do antenômero VII. Escapo preto, ligeiramente curvo na base. Pedicelo preto. Antenômero III preto com estreito anel apical esbranquiçado.

Antenômeros IV a VII brancos. Antenômero VIII branco com estreito anel apical acastanhado. Antenômeros IX a XI acastanhados (vide variações).

Protórax preto. Lados do pronoto com faixa de pubescência amarelada, estreita e longitudinal. Processo prosternal branco-amarelado.

Élitros pretos; região umeral com tegumento amarelado, prolongado, no máximo, até a metade anterior do élitro e estende-se para o dorso, obliquamente, da base ao meio sem tocar a sutura; carena umeral bem demarcada da base até a extremidade; ápices elitrais com espículo no lado externo.

Pro- e mesofêmures amarelo-esbranquiçados com ápices acastanhados; metafêmures amarelo-esbranquiçados com 
terço apical preto. Tíbias e tarsos pretos. Esternos torácicos e urosternitos pretos.

Variabilidade. Antenômeros IV e V brancos. Antenômero VI preto com estreito anel basal esbranquiçado. Antenômeros VII a XI pretos.

Dimensões em mm, respectivamente macho/fêmea. Comprimento total, 5,0/5,3; comprimento do protórax, 0,9/1,0; maior largura do protórax, 1,0/1,1; comprimento do élitro, 3,6/3,8; largura umeral, 1,4-1,6.

Material-tipo. Holótipo macho, EQUADOR, Napo: Alinahui, 14.IX.2000, F. T. Hovore col. (CASC). Parátipos: COLÔMBIA, Meta: Restrepo, 2.X.1965, J. A. Ramos col., 2 machos (MZSP) e 1 fêmea (USNM).

Discussão. Sybaguasu mirim sp. nov. é semelhante a Sybaguasu subcarinatus (Bates, 1885) pelos antenômeros III e IV brancos e pelo pronoto com faixas longitudinais branco-amareladas. Distingue-se pelos élitros com carena umeral contínua da base ao ápice. Em $S$. subcarinatus, que desconhecemos, a carena elitral é incompleta, "obtusa ante medium evanescente", e as faixas laterais do protórax são mais largas.

\section{Potiapunga gen. nov.}

Etimologia. Tupi, potiâ = peito; punga = inchaço; alusivo ao tubérculo nos lados do protórax. Gênero feminino.

Espécie-tipo, Potiapunga lata sp. nov.

Macho. Fronte sem projeções. Lobos oculares superiores tão distantes entre si quanto a largura de um lobo. Antenas com onze artículos alcançam o terço apical dos élitros. Escapo robusto, curto, gradualmente engrossado para o ápice; comprimento igual à metade do antenômero III. Antenômero III com pelos longos em toda superfície e com o triplo do comprimento do IV. Antenômero IV com pelos longos no lado interno e curtíssimos no lado externo. Artículos V a X sem pelos curtos e com comprimentos gradualmente decrescentes. Antenômero XI não aculeado.

Protórax mais largo do que longo. Lados do protórax, no terço basal, com grande tubérculo de ápice arredondado. Pronoto com gibosidade discreta centro-basal.

Élitros alargados no terço central, aplanados, sem carenas. Epipleuras com franja de pelos longos na metade anterior. Extremidades arredondadas.

Procoxas projetadas e muito próximas, pois o processo prosternal é muito estreito. Fêmures sublineares. Ápices dos metafêmures ultrapassam o urosternito II. Tíbias com franja de pelos curtos e densos no lado externo. Dente interno das garras tarsais pouco mais curto que o externo.

Discussão. Antenômeros III e IV com pelos longos, protórax com grande tubérculo lateral e élitros expandidos no terço central, sem carenas e pilosos nas margens no terço anterior constituem conjunto de caracteres peculiares para Potiapunga gen. nov. O gênero Dadoycus Chevrolat, 1833, poderia ser comparado com Potiapunga, mas é bastante diverso. Em Dadoycus apenas o antenômero III é ligeiramente engrossado, com pelos curtos, o antenômero IV não tem franja de pelos; o protórax não tem tubérculo lateral, os élitros não são expandidos e não têm pelos nas epipleuras.

\section{Potiapunga lata sp. nov.}

(Fig. 2)

Etimologia. Latim, latus $=$ largo, alusivo ao aspecto dos élitros.

Cabeça com tegumento avermelhado coberto por pubescência esbranquiçada; regiões atrás dos olhos pretas. Escapo preto. Pedicelo preto com anel basal amarelado. Antenômeros III a IX pretos com anel basal amarelado. Protórax com tegumento alaranjado. Pronoto com pilosidade esbranquiçada e relativamente longa; pontuação coberta pela pilosidade. Escutelo e élitros pretos. Procoxas e profêmures alaranjados. Protíbias (menos ápices) alaranjadas com franja de pelos curtos e densos nas margens anteriores $(25 \mathrm{x})$. Pernas médias, posteriores e esternos torácicos, pretos.

Dimensões em mm, holótipo macho. Comprimento total, 9,4; comprimento do protórax, 1,4; maior largura do protórax, 2,5; comprimento do élitro, 7,1; largura umeral, 2,7; maior largura dos élitros, 3,6.

Material-tipo. Holótipo macho, BOLÍVIA, Santa Cruz: Buena Vista (4 km SSE, Hotel Flora \& Fauna, 17²9'S, 6339'W, 300-400 m), 1720.X.2011, Wappes \& Skilman col. (MNKM).

\section{Cotyabanycha gen. nov.}

Etimologia. Tupi, coty = ao lado de abanych $a=$ nome de gênero de Hemilophini. Gênero masculino.

Espécie-tipo, Cotyabanycha ocularis sp. nov.

Fronte dos machos sem projeções. Olhos divididos. Lobos oculares inferiores grandes, mais longos do que as genas, muito convexos. Lobos oculares superiores com dez fileiras de omatídios, tão distantes entre si quanto o dobro da largura de um lobo e separados dos inferiores por única fileira de omatídios. Antenas (macho) atingem as extremidades dos élitros, aproximadamente, no meio do antenômero VI. Escapo cilíndrico, ligeiramente curvo na base. Antenômero III longo, a ponta atinge aproximadamente o meio dos élitros, com 1,7 vez o comprimento do escapo e 1,4 vez o comprimento do antenômero IV. Antenômeros V a X com comprimentos decrescentes. Antenômero XI não modificado.

Protórax mais longo do que largo, com lados apenas gibosos no meio. Pronoto regularmente convexo.

Élitros sem carena umeral. Extremidades elitrais emarginadas com espinho externo.

Fêmures sublineares. Meio da face externa dos mesofêmures com faixa de pequenas saliências $(50 \mathrm{x})$ em toda extensão. Garras tarsais com dente interno apenas mais curto que o externo.

Discussão. Cotyabanycha gen. nov. assemelha-se a Abanycha Martins \& Galileo, 1997, entretanto a ausência de carena nos élitros é uma diferença considerável. Abanycha 
tem duas carenas em cada élitro, uma umeral e outra próxima e paralela.

Dentre os gêneros sem carena nos élitros, Cotyabanycha assemelha-se mais a Pseudegalicia Galileo \& Martins, 2001 e difere pelas extremidades elitrais emarginadas com espinho curto externo, pelos lobos oculares inferiores bem globosos e pelo antenômero III muito longo que atinge o meio dos élitros. Em Pseudegalicia as extremidades dos élitros são arredondadas em conjunto, os lobos oculares inferiores têm convexidade normal e o antenômero III atinge a base dos élitros.

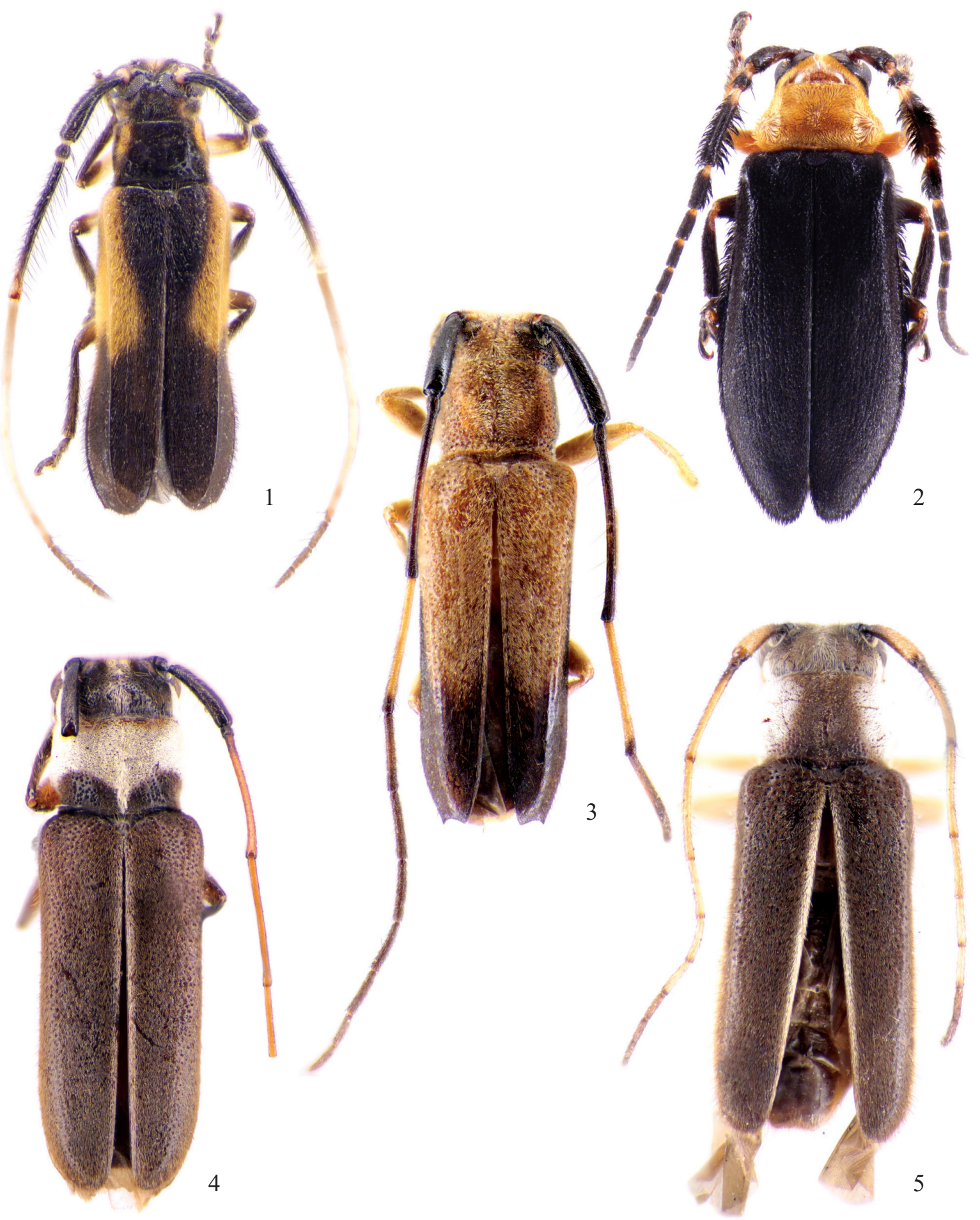

Figs. 1-5. 1. Sybaguasu mirim sp. nov., holótipo macho, comprimento 5,0 mm; 2. Potiapunga lata sp. nov., holótipo macho, comprimento $9,4 \mathrm{~mm} ; 3$. Cotyabanycha ocularis sp. nov., holótipo macho, comprimento 7,2 mm; 4. Eranina sororcula sp. nov., holótipo macho, comprimento 7,8 mm; 5. Eranina pallida sp. nov., holótipo fêmea, comprimento $7,0 \mathrm{~mm}$. 


\section{Cotyabanycha ocularis sp. nov.}

(Fig. 3)

Etimologia. Latim, ocularis $=$ dos olhos, alusivo aos olhos divididos.

Cabeça com tegumento alaranjado, mas preto atrás dos olhos. Labro com tegumento esbranquiçado na parte superior. Fronte e vértice com pubescência esbranquiçada visível conforme a incidência da luz. Escapo preto; o ápice alcança o terço basal do pronoto. Pedicelo e antenômero III pretos. Antenômero IV amarelado, menos anel apical, preto. Antenômeros V a XI pretos.

Protórax laranja-avermelhado. Pronoto finamente pontuado, com pubescência esbranquiçada visível conforme a incidência da luz. Mesosterno preto, menos o processo mesosternal. Meso- e mesepimeros pretos e pontuados. Metepisternos pretos. Metasterno preto nos lados e alaranjado no centro, com pontos nos lados.

Élitros alaranjados nos $2 / 3$ anteriores e pretos no terço apical, essa coloração prolonga-se para frente, pelas epipleuras até os úmeros; pubescência esbranquiçada visível conforme a incidência da luz.

Fêmures e protíbias alaranjados. Meso- e metatíbias pretas com bases alaranjadas. Tarsos amarelados.

Urosternitos alaranjados, com pubescência esbranquiçada.

Dimensões em mm, holótipo macho. Comprimento total, 7,2; comprimento do protórax, 1,4; maior largura do protórax, 1,7; comprimento do élitro, 5,1; largura umeral, 2,1. Antenas: comprimento do escapo, 1,5; antenômero III, 2,5; antenômero IV, 1,8.

Material-tipo. Holótipo macho, COSTA RICA, Limón: Bataán, 16.VI.1951, O. L. Cartwright col. (USNM).

\section{Eranina sororcula sp. nov.}

(Fig. 4)

Etimologia. Latim, sororcula = diminutivo de soror, irmã. Alusivo à semelhança com Eranina leuconoe Bates, 1881.

Cabeça com tegumento preto ou acastanhado, com faixa de pubescência branca, esparsa desde entre os tubérculos anteníferos até o occipício e faixa de pubescência branca, densa, atrás dos olhos. Olhos divididos. Escapo, pedicelo e anel basal no antenômero III, pretos. Antenômeros III (base exceto) a V com tegumento alaranjado (antenas quebradas na ponta do antenômero $\mathrm{V}$ ).

Protórax com tegumento preto ou acastanhado. Pronoto densamente revestido por pubescência branca, compacta, menos: duas áreas desenvolvidas, semicirculares, que se estendem da base até o meio e que não se unem no meio com pubescência fina, esparsa, que não acoberta o tegumento. Esternos torácicos pretos ou acastanhados. Mesepisternos, metepisternos e lados do metasterno pontuados.

Élitros pretos ou castanhos, com pubescência esbranquiçada; a pubescência mais concentrada sobre o friso sutural. Extremidades elitrais sem espículo externo.
Profêmures alaranjados. Protíbias alaranjadas com linha preta na face dorsal. Mesofêmures alaranjados na base e na extremidade. Mesotíbias, metafêmures e metatíbias e tarsos, pretos.

Urosternitos pretos ou acastanhados; lados de III a V com pubescência branca.

Dimensões em mm, respectivamente macho/fêmea. Comprimento total, 7,8/8,5; comprimento do protórax, 1,5/1,6; maior largura do protórax, 2,0/2,6; comprimento do élitro, $5,8 / 6,0$; largura umeral, $2,4 / 2,8$.

Material-tipo. Holótipo macho, EL SAVADOR, La Libertad: Santa Tecla, 20.V.1954, P. A. Berry col. (USNM). Parátipo fêmea, EL SALVADOR, Cuscatlán: Rasaria (não localizado), 19.VII.1955, M. S. V. col. (MZSP).

Discussão. Eranina sororcula sp. nov. assemelha-se a $E$. leuconoe Bates, 1881, descrita da Nicarágua e do Panamá, que apresenta protórax com colorido praticamente igual. Entretanto, E. sororcula difere por apresentar a face ventral dos esternos torácicos sem pubescência branca densa. Em $E$. leuconoe "corpore subtus vitta lateral albo-tomentosa" (Bates 1881: 209).

\section{Eranina pallida sp. nov.}

(Fig. 5)

Etimologia. Latim, pallidus = pálido; alusivo à coloração corporal.

Mandíbulas com ápice bífido. Clípeo amarelado. Fronte com tegumento avermelhado com pubescência esparsa, esbranquiçada. Vértice castanho com pubescência esparsa, esbranquiçada; centro do occipício com pubescência esbranquiçada mais concentrada. Faixa estreita de pubescência branca atrás dos olhos. Olhos quase divididos, os lobos separados por única fileira incompleta de omatídios. Lobos oculares superiores com seis fileiras de omatídios, tão distantes entre si quanto o sexto da largura de um lobo. Antenas atingem os ápices dos élitros aproximadamente no ápice do antenômero $\mathrm{X}$. Escapo amarelado com a face interna mais acastanhada e pequeno anel apical preto. Pedicelo castanho. Antenômero III amarelado com estreito anel basal castanho. Antenômeros IV a VII amarelados e VIII a XI pretos.

Protórax com tegumento castanho. De cada lado do pronoto uma grande mancha de pubescência branca, compacta, que se prolonga até a metade superior das partes laterais do protórax. Metade inferior das partes laterais e prosterno avermelhados. Mesepisternos e mesepimeros vermelho-acastanhados e esparsamente pontuados. Metepisternos castanhos, esparsamente pontuados e finamente pubescentes. Metasterno vermelho-acastanhado com pontos esparsos nos lados. Escutelo castanho.

Élitros com tegumento castanho revestido por pubescência esbranquiçada que está mais concentrada sobre o friso sutural; friso marginal com tegumento amarelado. Extremidades elitrais arredondadas.

Fêmures amarelados; tíbias e tarsos castanhos. Urosternitos I a V castanho-amarelados; lados com pubescência branca e compacta. 
Dimensões em mm, holótipo fêmea. Comprimento total, 7,0; comprimento do protórax, 1,2; maior largura do protórax, 1,9; comprimento do élitro, 4,9; largura umeral, 2,2. Olhos: largura de um lobo ocular superior, 0,1 ; distância entre lobos superiores, 0,6 .

Material-tipo. Holótipo fêmea, HONDURAS, La Ceiba, 18.X.1916, F. J. Dyer col. (USNM). Não é possível saber qual o departamento, pois existem 17 topônimos em Honduras denominados La Ceiba.

Discussão. Antenas com tegumento amarelado (escapo inclusive) nos artículos III a VII e élitros com friso sutural coberto por pubescência esbranquiçada são caracteres raros em Eranina. A espécie que mais se assemelha a E. pallida $\mathbf{s p .}$ nov. é E. moysesi Galileo \& Martins, 2008, descrita da Costa Rica, embora apresente algumas diferenças. Em E. moysesi: o escapo é preto com mancha amarelada no lado interno; o antenômero III e os antenômeros VII a XI são pretos e os élitros são pretos sem pubescência esbranquiçada sobre o friso sutural.

\section{Piampatara antennata sp. nov.}

(Fig. 6)

Etimologia. Latim, antenna = antena; alusivo às antenas.

Cabeça alaranjada coberta por pubescência esbranquiçada. Fronte convexa e pontuada. Olhos inteiros. Lobos oculares superiores com dez fileiras de omatídios tão distantes entre si quanto o dobro da largura de um lobo. Antenas atingem os ápices dos élitros, aproximadamente, no meio do antenômero VII. Escapo preto com a face interna alaranjada (menos em curtos anéis apical e basal). Pedicelo preto com anel basal alaranjado. Antenômero III preto com estreito anel basal alaranjado, com quase o dobro do comprimento do escapo e provido de pelos moderadamente esparsos no lado interno. Antenômero IV amarelado com pequeno anel apical preto; comprimento subigual ao do escapo. Antenômero V amarelado com quarto apical preto. Antenômeros V a X pretos (antenas quebradas na ponta do antenômero X).

Protórax alaranjado. Pronoto pontuado com pubescência alaranjada mais concentrada da base ao meio dos lados. Partes laterais do protórax pontuadas.

Élitros alaranjados, com duas carenas em cada um, a externa apenas indicada; pubescência densa em toda superfície. Extremidades elitrais ligeiramente oblíquas e com espículo externo.

Pernas e face inferior do corpo amarelo-alaranjadas. Pubescência branco-amarelada reveste toda superfície, menos mancha amarelada no centro-posterior do metasterno.

Dimensões em mm, holótipo macho. Comprimento total, 7,2; comprimento do protórax, 1,5; maior largura do protórax, 1,8; comprimento do élitro, 4,9; largura umeral, 2,2. Antenas: comprimento do escapo, 1,1; antenômero III, 1,9; antenômero IV, 1,2.

Material-tipo. Holótipo macho, EQUADOR, Napo: Napo-Galeras "road", km 1, 25.VIII.2004, F. T. Hovore col. (CASC).
Discussão. Piampatara antennata sp. nov. assemelha-se a P. humeralis (Aurivillius, 1916). Distingue-se: antenômeros IV e V amarelados e élitros unicolores. Em P. humeralis os antenômeros IV e V são escuros e os élitros têm faixa transversal preta anteapical.

\section{Phoebe spegazzinii Bruch, 1908}

(Fig. 7)

Phoebe spegazzinii Bruch, 1908: 219, fig.; Monné, 2005: 495 (cat.).

Phoebe spegazzini, descrita da Argentina (Córdoba), é uma espécie bastante variável no colorido e foi figurada, quando descrita, pelo próprio Bruch e cuja descrição baseou-se em "varios ejemplares". Bruch declarou que os seus exemplares têm a ornamentação branca dos élitros "mas o menos variable" e talvez essa variação envolva o exemplar que ora descrevemos. Bachmann \& Di Iorio (2002: 81) anotaram apenas dois exemplares no MACN: o "typus" e um "syntypus".

Cabeça com tegumento castanho-escuro coberto por densa pubescência branca, mais esparsa na fronte. Fronte com elevação pouco projetada em forma de "U”. Escapo e pedicelo com tegumento preto, densamente cobertos por pubescência branca. Protórax com tegumento castanho-avermelhado coberto por pubescência branca; no pronoto pubescência branca mais concentrada, de cada lado, na orla de uma área elíptica e longitudinal.

Élitros com tegumento castanho-avermelhado, mais claro, cobertos por pubescência branca. Em cada élitro, a pubescência é mais compacta: (1) numa faixa transversal, levemente curva, no sexto anterior; (2) numa mancha triangular, fundida com a carena, na metade anterior que não atinge a sutura; (3) numa faixa semicircular no sexto apical e interligada por estreita faixa junto à sutura à mancha (4) que ocupa os ápices. Extremidades elitrais arredondadas.

Dimensões em mm, macho. Comprimento total, 12,0; comprimento do protórax, 2,1; maior largura do protórax, 2,5; comprimento do élitro, 9,0; largura umeral, 3,2.

Material examinado. EQUADOR, Manabi: "Vicinity of" Monte Cristi $\left(01,01534^{\circ} \mathrm{S}, 080,68195^{\circ} \mathrm{W}, 355 \mathrm{~m}\right)$, macho, $17-26 . I I .2006$, F. T. Hovore \& I. Swift col. (CASC).

Discussão. Bosq (1949: 201) registrou P. spegazzini para Santiago del Estero: Río Salado. Martins \& Galileo (1998: 431) apresentaram chave para as 14 espécies de Phoebe então conhecidas e incluíram uma figura do élitro esquerdo de P. spegazzini com o padrão de colorido bastante diverso daquele figurado por Bruch. Esse exemplar é procedente da Bolívia (MZSP).

Em 2003, Martins \& Galileo, registraram a acentuada variabilidade no padrão de colorido e figuraram um exemplar do Paraguai com apreciável redução das manchas brancas dos élitros.

Esta forma de P. spegazzinii distingue-se da forma típica e do exemplar figurado na descrição original (Bruch 1908: 219): 
fronte com projeção em forma de "U" invertido, que podem estar sujeitas a variações; pronoto coberto por pubescência branca mais concentrada, de cada lado, na orla de uma área elíptica e longitudinal; mancha triangular de pubescência branca, compacta, da metade anterior dos élitros não toca a sutura. $\mathrm{Na}$ forma típica, a fronte tem duas projeções alongadas visíveis na ilustração, mas não descritas por Bruch; o pronoto mostra quatro faixas de pubescência banca na base e a mancha triangular do meio dos élitros fundida com a sutura.

\section{Adesmus alboniger sp. nov.}

(Fig. 8)

Etimologia. Latim, albus = branco; niger $=$ negro, alusivo à coloração corporal.

Metade inferior da fronte com tegumento vermelho-acastanhado revestido por pubescência esparsa esbranquiçada; restante da cabeça com tegumento preto coberto por pubescência branca e densa; mancha pequena, glabra, entre os lobos oculares superiores. Olhos nitidamente divididos. Lobos oculares superiores tão distantes entre si quanto aproximadamente o dobro da largura de um lobo. Antenas atingem as pontas dos élitros na base do antenômero VI. Escapo, pedicelo, antenômeros III e IV com tegumento amarelado; $\mathrm{V}$ a XI com tegumento preto.

Protórax mais largo anteriormente do que na base com orla anterior de tegumento castanho-alaranjado e restante da superfície com tegumento preto. Pronoto coberto por densa pubescência branca, menos numa mancha preta, no meio. Partes laterais do protórax com faixa preta, longitudinal, no meio. Mesosterno preto. Mesepimeros, mesepisternos, metepisternos e lados do metasterno com tegumento alaranjado, cobertos por pubescência branca e densa. Meio de metasterno preto.

Élitros com tegumento castanho-avermelhado revestidos por densa pubescência esbranquiçada; cada um com: (1) faixa estreita, preta e brilhante que envolve os úmeros, segue posteriormente sobre a carena umeral até depois do meio, onde se curva em direção à margem; (2) faixa preta, transversal, estreita, no quarto apical; (3) faixa marginal, preta, mais larga anteriormente e restrita ao friso marginal para o ápice.

Pernas amareladas. Procoxas e prosterno com tegumento preto. Urosternitos I-IV com tegumento preto coberto por pubescência branca principalmente nos lados. Urosternito V preto no meio e com as bordas alaranjadas.

Dimensões em mm, holótipo macho. Comprimento total, 9,6; comprimento do protórax, 2,1; maior largura do protórax, 2,6; comprimento do élitro, 6,5; largura umeral, 3,3.

Material-tipo. Holótipo macho, EQUADOR, Napo: Alinahui, 14.IX.2000, F. T. Hovore col. (CASC).

Discussão. Adesmus alboniger sp. nov. é uma espécie muito característica pelo desenho dos élitros e pelos olhos divididos. Poderia ser comparada com A. beruri Martins \& Galileo, 2011 pela mácula preta no meio do pronoto e pelas pernas amareladas. Distingue-se de $A$. beruri, pelas faixas pretas dos élitros que envolvem os úmeros, prolonga-se posteriormente sobre a carena umeral até depois do meio, onde se curva em direção à margem (Fig. 8). Em A. beruri, as faixas pretas dos élitros (Martins \& Galileo 2011: 358, fig. 2) são transversais e em número de quatro (inclusive uma que envolve os ápices).

\section{Adesmus swifti sp. nov.}

(Fig. 9)

Etimologia. O nome específico é uma homenagem a Ian Swift (California State Collection of Arthropods, Sacramento, EUA) um dos coletores do holótipo.

Cabeça com tegumento castanho-avermelhado revestido por pubescência branca. Olhos inteiros, a união entre lobos com uma fileira de omatídios. Lobos oculares superiores largos, mais próximos entre si do que a largura de um lobo. Escapo castanho-avermelhado. Pedicelo e antenômero III amarelados; antenômeros IV a XI gradualmente escurecidos em direção ao ápice. Franja de pelos dos antenômeros esparsa; os pelos mais longos que a largura dos flagelômeros.

Protórax castanho-avermelhado. Pronoto quase inteiramente coberto por pubescência branca, densa, que ocupa grande parte da superfície e deixa apenas uma estreita faixa avermelhada que é a continuação das partes laterais do protórax. Escutelo coberto por pubescência branca, densa. Prosterno, mesosterno, mesepimeros e metepisternos pretos. Mesepisternos preto-avermelhados. Metasterno preto com lados preto-avermelhados.

Élitros com tegumento vermelho-alaranjado cobertos por pubescência esbranquiçada, esparsa; cada um com três manchas de pubescência branca, densa: uma dorsal, no terço anterior, triangular e que vista em conjunto com a que lhe corresponde no outro élitro é cordiforme; outra, dorsal, elíptica, logo atrás do meio, soldada com a sutura; uma terceira, também dorsal, elíptica, no quarto apical e fundida com a sutura. Entre estas duas últimas manchas a pubescência branca é mais densa de sorte que as manchas estão ligadas. Extremidades elitrais obliquamente truncadas com projeção externa.

Pernas amareladas. Procoxas amareladas e pretas posteriormente. Mesocoxas pretas. Urosternitos I a IV pretos. Urosternito $\mathrm{V}$ preto no centro com as margens amareladas.

Dimensões em mm, holótipo macho. Comprimento total, 6,3 comprimento do protórax, 1,1; maior largura do protórax, 1,4; comprimento do élitro, 4,6; largura umeral, 1,7.

Material-tipo. Holótipo macho, EQUADOR, Loja: Gonzanama $(18 \mathrm{~km} \mathrm{~N}$, $04^{\circ} 08^{\prime} 08,5^{\prime \prime}$ S, 79²3'36,4"W), 24.II.2006, F. T. Hovore \& I. Swift col. (CASC).

Discussão. Adesmus swifti sp. nov., por apresentar seis manchas de pubescência branca nos élitros e pronoto com grande área coberta por pubescência branca, densa, pode ser comparada $\operatorname{com} A$. meinerti (Aurivillius, 1900) da Venezuela, A. stellatus Galileo \& Martins, 2005, da Costa Rica e $A$. windsori Martins \& Galileo, 2004, do Panamá. 


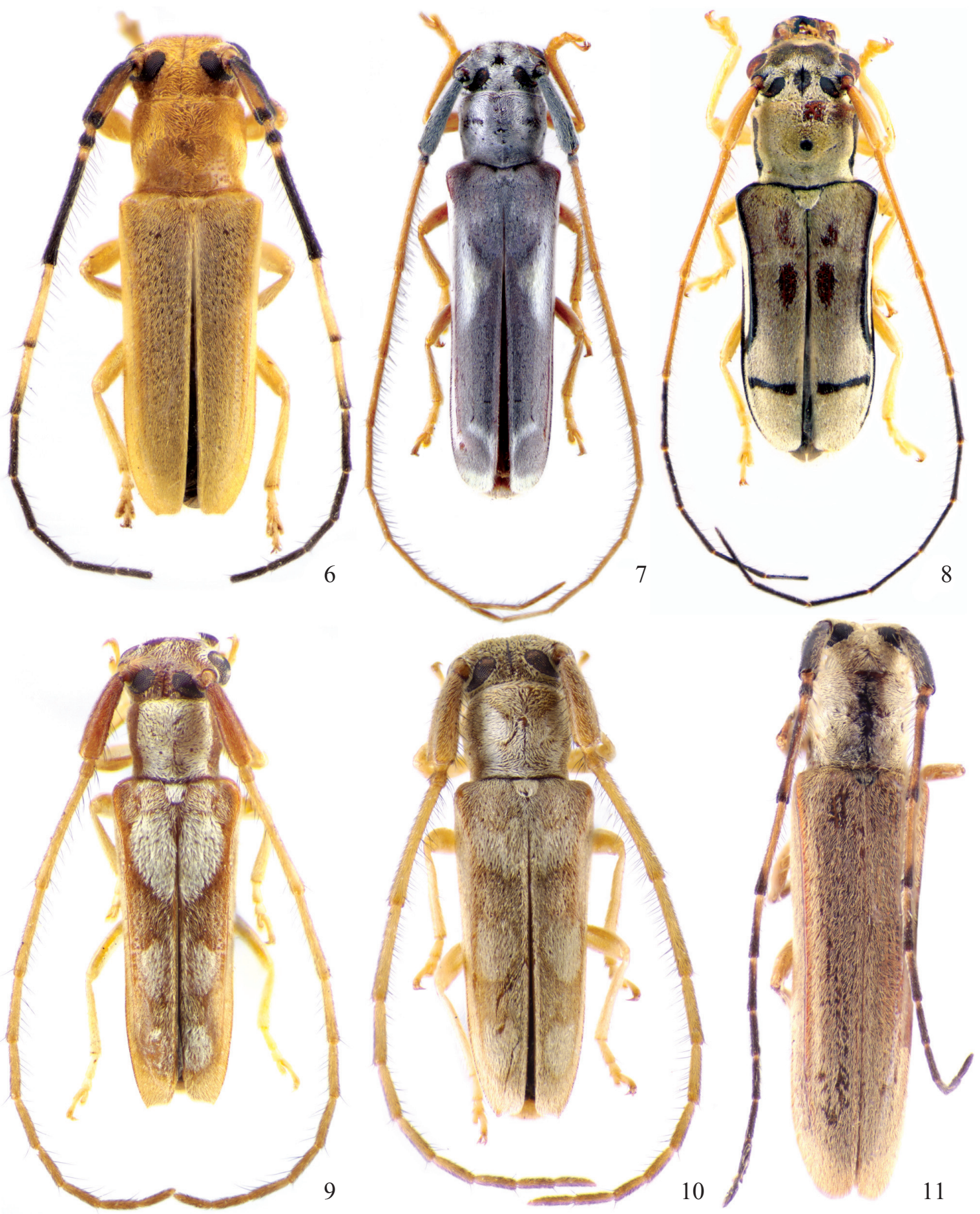

Figs. 6-11. 6. Piampatara antennata sp. nov., holótipo macho, comprimento 7,2 mm; 7. Phoebe spegazzinii Bruch, 1908, macho, comprimento 12,0 mm; 8. Adesmus alboniger sp. nov., holótipo macho, comprimento 9,6 mm; 9. Adesmus swifti sp. nov., holótipo macho, comprimento 6,3 mm; 10. Adesmus simile sp. nov., holótipo macho, comprimento 7,3 mm; 11. Mexicoscylus nigritarse sp. nov., holótipo fêmea, comprimento 7,5 mm.

Adesmus swifti difere de A. meinerti pelo pronoto sem faixa no meio da área branca e pelas manchas dos élitros com contornos muito mais regulares. Em A. meinerti, o pronoto tem faixa curta, avermelhada, no centro-posterior e as manchas dos élitros têm contornos muito irregulares.

Separa-se de A. stellatus pela mancha de pubescência bran- ca que ocupa grande parte do pronoto, pelo escapo castanhoavermelhado e pela face ventral do corpo preta em vários esternitos. Em A. stellatus a pubescência branca ocupa área mais estreita no pronoto e encerra faixa alaranjada centro-posterior, o escapo é preto e a face ventral do corpo é uniformemente alaranjada. 
Distingue-se de $A$. windsori pelo escapo castanho-avermelhado e antenômeros V a XI amarelados e gradativamente mais acastanhados em direção ao ápice e pela mancha de pubescência branca do pronoto fundida com a base. Em $A$. windsori o escapo é preto, os antenômeros V a XI são castanhos ou pretos e a mancha de pubescência branca do pronoto não alcança a base.

\section{Adesmus simile sp. nov.}

(Fig. 10)

Etimologia. Latim, simile = semelhante; alusivo a semelhança com Adesmus swifti.

Cabeça com tegumento acastanhado coberta por pubescência esbranquiçada, densa. Olhos inteiros nas fêmeas e quase divididos nos machos (uma fileira de omatídios separados). Antenas amarelo-alaranjadas, gradualmente acastanhadas para o ápice; alcançam a extremidade dos élitros, aproximadamente, no ápice do antenômero VI (macho) ou do VII (fêmea). Escapo robusto, preto na face ventral, revestido por pubescência branco-amarelada. Flagelômeros basais com franja de pelos castanho-escuros no lado interno.

Protórax com tegumento castanho-avermelhado coberto por pubescência branco-amarelada.

Élitros com tegumento castanho-avermelhado revestido por pubescência branco-amarelada; cada um com três manchas de pubescência esbranquiçada pouco contrastantes e pouco aparentes: (1) no terço anterior, em forma de "V" com ramos muito abertos, soldada com a sutura; (2) depois do meio, dorsal, arredondada; (3) inaparente, elíptica, no quarto apical. Essas manchas são circundadas por colorido acastanhado, mais visível nas fêmeas. Extremidades elitrais truncadas, levemente emarginadas com espículo externo.

Prosterno (inclusive processo prosternal), mesosterno (inclusive processo mesosternal), centro de metasterno e urosternito I e meio do urosternito II, com tegumento preto. $\mathrm{Na}$ fêmea, esse colorido preto é mais visível e também aparece na base dos urosternitos. Pernas amareladas.

Dimensões em mm, holótipo macho/parátipo fêmea. Comprimento total, 7,3/6,7; comprimento do protórax, 1,6/ 1,5; maior largura do protórax, 1,7/1,5; comprimento do élitro, 4,8/4,6; largura umeral, 2,1/2,0.

Material-tipo. Holótipo macho, EQUADOR, Manabi: vicinity of La Pila, 01.11198 S, 080.58068 W, 200 m), 18-27.II.2006, F. T. Hovore \& I. Swift col. (CASC).

Parátipo fêmea, com os mesmos dados do holótipo (MZSP).

Discussão. Adesmus simile sp. nov. e A. swifti sp. nov. são bastante semelhantes, pelas pequenas dimensões e pelas três manchas de pubescência branca em cada élitro. $A$. simile difere de $A$. swifti (comparação entre machos): pelo vértice com densa pubescência; pelo escapo mais robusto (Figs. 9, 10); pelos lados do protórax inteiramente cobertos por pubescência branco-amarelada; pelos ápices dos élitros truncados; pela face inferior do corpo densamente coberta por pubescência branco-amarelada. Em $A$. swifti, o vértice é praticamente glabro; o escapo é mais esbelto; os lados do protórax são praticamente glabros e essa faixa glabra é visível nos lados do pronoto; os ápices dos élitros são obliquamente truncados e a parte inferior do corpo é revestida por pubescência branca e esparsa.

\section{Mexicoscylus nigritarse sp. nov.}

(Fig. 11)

Etimologia. Latim, nigrum $=$ preto; tarsi $=$ tarsos, alusivo à coloração dos tarsos.

Cabeça com tegumento castanho-avermelhado, revestida por pubescência esbranquiçada, densa. Vértice coberto por pubescência esbranquiçada, menos numa faixa de cada lado com pubescência acastanhada, convergentes (aproximam-se, mas não se tocam no occipício), pouco contrastantes, atrás dos lobos oculares superiores. Outra faixa acastanhada atrás dos lobos oculares inferiores. Lobos oculares superiores tão distantes entre si quanto à largura de um lobo.

Antenas atingem as extremidades dos élitros, aproximadamente, na extremidade do antenômero IX. Escapo cilíndrico, preto na face interna e avermelhado na externa. Pedicelo preto com anel basal alaranjado. Antenômero III acastanhado no lado externo e avermelhado no lado interno; ápice com anel preto; franja de pelos longos e pretos no lado interno; comprimento do antenômero III subigual ao do escapo. Antenômero IV alaranjado com anel apical preto; 1/3 mais curto que o III. Antenômeros V e VI pretos com a base alaranjada. Antenômeros VII a XI pretos com comprimentos decrescentes.

Protórax com tegumento castanho-avermelhado. Pronoto com faixa centro-longitudinal castanho-escura e glabra, coberta, nos lados, por pubescência castanha; restante da superfície pronotal revestida por pubescência esbranquiçada e densa. Partes laterais do protórax com faixa longitudinal acastanhada. Escutelo preto.

Élitros com tegumento castanho-avermelhado, mais escuro na carena umeral que se estende até perto do ápice; pubescência elitral acastanhada; no lado interno da carena, uma faixa longitudinal estreita de pubescência esbranquiçada; pontuação elitral organizada em fileiras longitudinais no disco. Ápices elitrais arredondados.

Fêmures alaranjados. Protíbias pretas no meio da margem anterior. Meso- e metatíbias escurecidas no meio da margem posterior e com anel apical preto. Tarsômeros I e II amarelados e III a V pretos. Dente interno das garras tarsais mais curto que o externo.

Toda face ventral do corpo coberta por pubescência esbranquiçada. Mesosterno e mesepimeros castanhoavermelhados. Metasterno preto no meio e gradualmente mais avermelhado para os lados. Urosternito V tão longo quanto o dobro do IV com borda apical levemente emarginada.

Dimensões em mm, holótipo fêmea. Comprimento total, 7,5; comprimento do protórax, 1,3; maior largura do protórax, 1,3; comprimento do élitro, 5,6; largura umeral, 1,8. 
Material-tipo. Holótipo fêmea, COSTA RICA, Guanacaste: R. Naranjo (3 km SE), 1-14.IX.1993, F. D. Parker col. (LGBC).

Discussão. Mexicoscylus foi descrito por Martins \& Galileo (2011) para conter M. rosae Martins \& Galileo, 2011 e $M$. bivittatus (Gahan, 1892), ambas conhecidas do México. Mexicoscylus nigritarse sp. nov. apresenta ápices dos élitros arredondados como $M$. bivittatus, segundo a fotografia do holótipo (Bezark 2012), mas apresenta outros caracteres oculares que ampliam o conceito do gênero: o estreitamento dos olhos entre os lobos tem uma fileira de omatídios (três em M. rosae); os lobos oculares superiores são tão separados entre si quanto à largura de um lobo (triplo da largura em $M$. rosae).

Mexicoscylus nigritarse distingue-se de M. rosae: pelo colorido corporal castanho-avermelhado; pelos flagelômeros apicais pretos; pela ausência de faixas estreitas de pubescência branca no vértice e nos lados do pronoto; pelos fêmures alaranjados, pelos ápices dos élitros arredondados e pelos tarsômeros I e II amarelados e III a V pretos. Em M. rosae: o colorido corporal é preto; os flagelômeros apicais são anelados; faixas estreitas de pubescência branca atrás dos lobos oculares superiores e nos lados do pronoto; fêmures pretos; extremidades elitrais com espinho externo e tarsômeros I a V pretos.

\section{AGRADECIMENTOS}

Aos que nos enviaram material para estudo: James E. Wappes, American Coleoptera Museum, que nos remeteu o material do USNM e informou que o material-tipo das espécies bolivianas deve ser depositado no MNKM; Larry G. Bezark, California Department of Food and Agriculture, que enviou exemplares coletados por F. T. Hovore no Equador e cujos holótipos pertencem à CASC. A Eleandro Moysés (Bolsista PIBIC/CNPq/FZB) pelas imagens e tratamento digital.

\section{REFERENCIAS}

Bachmann, A.O. \& Di Iorio, O. 2002. Types and related specimens of Cerambycidae and Disteniidae (Coleoptera) from the Museo Argentino de Ciencias Naturales "Bernardino Rivadavia", Buenos Aires, Argentina. Revista del Museo Argentino de Ciencias Naturales Bernardino Rivadavia (N. S.) 4: 55-93.

Bates, H.W. 1881. Biologia Centrali-Americana, Insecta, Coleoptera. v. 5, London, p. 153-224.

Bezark, L.G. 2012. A Photographic Catalog of the Cerambycidae of the World. Disponível em: http://plant.cdfa.ca.gov/byciddb/default_wImage.asp (acessado em junho de 2012).

Bosq, J.M. 1949. Anotaciones relativas a una lista de fauna local sobre cerambícidos argentinos. Revista de la Sociedad Entomológica Argentina 14: 194-203.

Bruch, C. 1908. Longicórnios argentinos nuevos o poco conocidos. I. Revista del Museo de La Plata 15: 198-220.

Galileo, M.H.M. \& Martins, U.R. 1999. O gênero Adesmus (Coleoptera, Cerambycidae, Lamiinae, Hemilophini). Iheringia, Zoologia, 86: 77-116.

Galileo, M.H.M. \& Martins, U.R. 2008. Eranina Monné (Coleoptera, Cerambycidae, Lamiinae) e novo genero de Hemilophini. Revista Brasileira de Entomologia 52: 384-389.

Martins, U.R. \& Galileo, M.H.M. 1998. Gêneros de Hemilophini (Coleoptera, Cerambycidae) semelhantes a Phoebe Audinet-Serville, 1835. Revista Brasileira de Entomologia 41: 431-437.

Martins, U.R. \& Galileo, M.H.M. 2003. Novas espécies e nota sobre Lamiinae (Coleoptera, Cerambycidae) neotropicais da coleção Arriagada, Santiago, Chile. Revista Brasileira de Entomologia 47: 615-620

Martins, U.R. \& Galileo, M.H.M. 2004. Sobre Hemilophini (Coleoptera, Cerambycidae, Lamiinae) da Região Neotropical: espécies novas e novos registros. Revista Brasileira de Zoologia 21: 535-541.

Martins, U.R. \& Galileo, M.H.M. (2010) 2011. Novos táxons de Hemilophini (Coleoptera, Cerambycidae, Lamiinae) das Américas. Iheringia, Zoologia, 100: 356-360.

Monné, M.A. 2005. Catalogue of the Cerambycidae (Coleoptera) of the Neotropical region. Part II. Subfamily Lamiinae. Zootaxa 1023: 1-759. 